OPEN ACCESS

Edited by:

Gabriele Pradel,

RWTH Aachen University, Germany

Reviewed by:

llia Voskoboinik,

Peter MacCallum Cancer

Centre, Australia

Ruby Hong Ping Law, Monash University, Australia

Michael Walch,

Université de Fribourg, Switzerland

${ }^{*}$ Correspondence: Natasa Strbo

nstrbo@med.miami.edu

Specialty section:

This article was submitted to

Microbial Immunology,

a section of the journal

Frontiers in Immunology

Received: 21 April 2020

Accepted: 08 July 2020

Published: 14 August 2020

Citation:

O'Neill K, Pastar I, Tomic-Canic M and Strbo N (2020) Perforins Expression by Cutaneous Gamma Delta T Cells.

Front. Immunol. 11:1839. doi: 10.3389/fimmu.2020.01839

\section{Perforins Expression by Cutaneous Gamma Delta T Cells}

\author{
Katelyn O'Neill ${ }^{1}$, Irena Pastar ${ }^{2}$, Marjana Tomic-Canic ${ }^{2}$ and Natasa Strbo ${ }^{1 *}$ \\ ${ }^{1}$ Department of Microbiology and Immunology, Miller School of Medicine, University of Miami, Miami, FL, United States, \\ ${ }^{2}$ Wound Healing and Regenerative Medicine Research Program, Dr. Phillip Frost Department of Dermatology and Cutaneous \\ Surgery, Miller School of Medicine, University of Miami, Miami, FL, United States
}

Gamma delta (GD) T cells are an unconventional T cell type present in both the epidermis and the dermis of human skin. They are critical to regulating skin inflammation, wound healing, and anti-microbial defense. Similar to CD8+ cytotoxic T cells expressing an alpha beta (AB) TCR, GD T cells have cytolytic capabilities. They play an important role in elimination of cutaneous tumors and virally infected cells and have also been implicated in pathogenicity of several autoimmune diseases. T cell cytotoxicity is associated with the expression of the pore forming protein Perforin. Perforin is an innate immune protein containing a membrane attack complex perforin-like (MACPF) domain and functions by forming pores in the membranes of target cells, which allow granzymes and reactive oxygen species to enter the cells and destroy them. Perforin-2, encoded by the gene MPEG1, is a newly discovered member of this protein family that is critical for clearance of intracellular bacteria. Cutaneous GD T cells express both Perforin and Perforin-2, but many questions remain regarding the role that these proteins play in GD T cell mediated cytotoxicity against tumors and bacterial pathogens. Here, we review what is known about Perforin expression by skin GD T cells and the mechanisms that contribute to Perforin activation.

Keywords: pore forming proteins, perforin, perforin-2, mpeg-1, gamma delta T cells, skin, cytotoxicity

\section{INTRODUCTION}

Gamma delta (GD) $\mathrm{T}$ cells are an unconventional $\mathrm{T}$ cell type that constitutes about $1-5 \%$ of circulating lymphocytes $(1,2)$. Despite low numbers in circulation, GD T cells are enriched in barrier tissues including the skin, gut, and reproductive tract (3-8). The skin is an epithelial tissue that serves as a barrier to protect against physical and chemical insults as well as potentially pathogenic microorganisms. It is composed of two main layers, the epidermis and dermis, and GD T cells are present in both layers in both mice and humans (2, 9). Epidermal GD T cells in mice are referred to as dendritic epidermal $\mathrm{T}$ cells (DETCs) because of the dendritic processes they use to survey surrounding keratinocytes for signs of stress or damage $(10,11)$. These cells all express an identical invariant TCR and are potent producers of IFN-g (12-14). Dermal GD T cells on the other hand are not dendritic and they produce IL-17 $(5,6)$. Human GD T cells, however, exist primarily in the dermis $(15,16)$. Small numbers are observed in the epidermis in steady state, but unlike mouse DETCs, they do not exhibit dendritic processes (17). Human GD T cells also express an invariant TCR. Skin resident cells express a delta $1 \mathrm{TCR}$, while circulating GD T cells express a delta 2 TCR (18-20). 
In recent years, researchers have begun to elucidate the vast roles that GD $\mathrm{T}$ cells play in skin inflammation and antimicrobial defense. GD $\mathrm{T}$ cells serve as bridges between the innate and adaptive immune system. Although they express a recombinant TCR as alpha beta $(\mathrm{AB}) \mathrm{T}$ cells do, they can bind to and recognize antigens directly without processing and presentation by MHC molecules (21). They can also respond to antigens without the need for pre-stimulation $(6,22)$. These innate-like characteristics position GD T cells to respond quickly to signs of stress caused by damage or infection. GD T cells play an important role in the response to pathogens in the skin. They produce IL-17 and IL-22 upon stimulation with IL-23, which triggers antimicrobial peptide production by keratinocytes as well as neutrophil recruitment to the site of infection $(5,9$, 23). GD T cells also contribute to wound healing, particularly through their production of fibroblast growth factor-7 (FGF7) and insulin-like growth factor-1 (IGF-1), which promote keratinocyte proliferation and reepithelialization $(24,25)$, as well as through their production of IL-17 (26). They also secrete fibroblast growth factor-9 (FGF-9), which triggers Wnt activation in wound fibroblasts and modulates hair follicle regeneration after wounding (27). In addition, GD $\mathrm{T}$ cells play a role in tumor surveillance. They have the ability to kill a variety of cutaneous tumors including melanoma and carcinomas, and they express cytotoxic molecules including Perforins and granzymes $(18,28,29)$. Although researchers have documented Perforin production by GD $\mathrm{T}$ cells, the mechanisms regulating Perforin production and the pathways through which it stimulates GD T cell cytotoxicity are not fully understood. This review will cover what is known about the role of Perforin as well as the novel pore forming protein Perforin-2 in GD T cells in the skin.

\section{OVERVIEW OF THE PERFORINS}

Some of the most well-characterized pore forming proteins include the pore forming toxins expressed by pathogenic bacteria (30). One example is the cholesterol dependent cytolysins (CDC) which are produced by several gram-positive bacterial species. These virulence factors promote bacterial pathogenesis by lysing or permeabilizing host cell membranes or intracellular organelles (30-32). CDC proteins share a complex core fold with proteins from the membrane attack complex/perforin (MACPF) superfamily (33-35). This structural homology underlies the similar mechanism of pore formation and membrane disruption shared by both protein families. Pore forming proteins in the MACPF family are named as such because they all contain a domain that is shared by the proteins that form the membrane attack complex and the Perforins (36). Hundreds of MACPF domain- containing proteins have been identified, but some of the most well-characterized are the mammalian MACPF immune proteins, which include complement proteins C6-C9, Perforin, and Perforin-2 $(34,37,38)$. Perforin, encoded by the gene $P R F 1$, is located within cytolytic granules inside cytotoxic $\mathrm{T}$ cells and natural killer (NK) cells (39). When the cytotoxic cell recognizes a transformed or infected target cell, the granules containing Perforin, granzymes, and granulysin migrate to the cell membrane and release their contents into the immune synapse (40). Perforin binds to the plasma membrane of the target cell and forms pores in the cell membrane, allowing delivery of cytolytic effector proteins and subsequent destruction of the cell (39-41). Perforin-2, encoded by the gene MPEG1, is a recently discovered innate immune protein that is highly conserved throughout the animal kingdom (42-44). Perforin2 is the more ancient of the two Perforins and it is thought that Perforin originated as a gene duplication of MPEG1 (45). Perforin-2 differs from other MACPF pore formers in that it has a transmembrane domain and localizes to endosomal membranes. The Perforin-2 cytosolic tail directs the endosomes to bacteria- encapsulating phagosomes (46). Acidification of the phagosome stimulates reconfiguration of the MACPF domain, resulting in pore formation on the bacterial cell membrane $(46,47)$. Our group was the first to demonstrate the essential role of Perforin-2 in eliminating intracellular bacterial infections $(48,49)$, confirming the importance of this protein as an antimicrobial effector protein expressed by both phagocytic and tissue forming cells.

\section{PERFORIN EXPRESSION BY SKIN GD T CELLS}

The tumor-lysing capabilities of GD $\mathrm{T}$ cells have been welldocumented in human skin (Figure 1A). Human skin derived GD $\mathrm{T}$ cells were purified using single cell sorting and tested in cytotoxicity assays against a variety of melanoma cell lines. They demonstrated cytotoxicity against SK-Mel2 and HS-294 melanoma cells, resulting in up to $90 \%$ cell death. This was comparable to the cytotoxic activity of the CD8+ AB T cells and NK cells that were also tested (18). GD T cells, CD8+ AB T cells, and NK cells only expressed Perforin after being cultured in the presence of IL-2, which is a previously established mechanism of Perforin induction in cytotoxic CD8+ T cells $(18,50,51)$. Murine cutaneous Vdelta1+ GD T cells also express Perforin both at the mRNA and protein levels (51). They exhibited cytotoxicity against several tumor cell lines and also expressed granzyme $\mathrm{B}$ in amounts comparable to cytotoxic $\mathrm{CD} 8+\mathrm{AB}$ $\mathrm{T}$ cells. Cytotoxic GD and AB T cells both produced IFN$\mathrm{g}$ and TNF-a $(18,52,53)$. Additionally, increased numbers of circulating CD3+TCR GD+ cells were observed in melanoma patients in comparison to healthy controls. These cells highly expressed Perforin in both normal individuals and melanoma patients, which may be important to anticancer surveillance (54). However, a study using a mouse model of skin carcinoma reported that circulating IL-17 producing GD T cells supported cutaneous tumor progression by promoting angiogenesis (55). In contrast to cytotoxic skin resident GD T cells, these non-skin resident IL-17 producing GD T cells that infiltrated the skin after tumor formation expressed low levels of Perforin and increased levels of the tumor-promoting factor COX-2. Although this paper did not establish a causative link between reduced Perforin expression and IL-17 production by circulating GD $\mathrm{T}$ cells, it implies that low levels of Perforin in these cells may contribute to their lack of cytotoxic activity and allow them to acquire a 

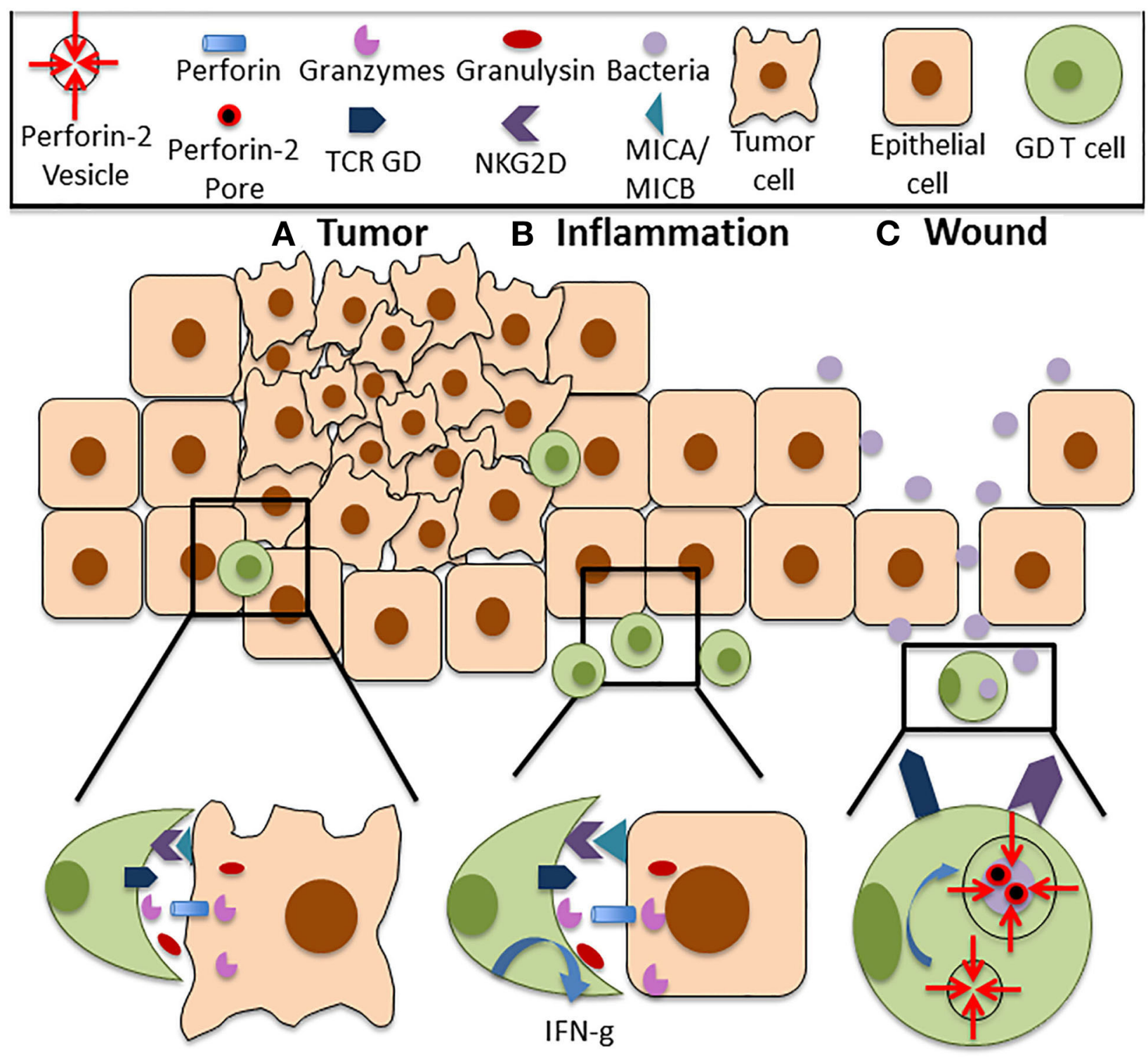

Perforin

Perforin

Perforin-2

FIGURE 1 | Functions of Perforin in cutaneous GD T cells. (A) Cutaneous GD T cells exhibit cytotoxicity against an array of tumor cell types, and this is associated with Perforin expression both at the mRNA and protein level. Perforin is located within cytolytic granules inside cytotoxic GD T cells and they are released upon degranulation into the immune synapse. Perforin binds to the plasma membrane of the target cell and forms pores in the cell membrane, allowing granzymes, granulysin, and reactive oxygen species to enter the cell and destroy it. Cytotoxic GD T cells can become activated through TCR stimulation or through ligation of several costimulatory surface molecules, particularly NKG2D. NKG2D recognizes the stress induced ligands MICA and MICB, and NKG2D signaling is sufficient for activation of skin GD T cell cytotoxicity. (B) Perforin expressing GD T cells are also implicated in autoimmune and inflammatory skin diseases. Increased percentages of GD T cells have been observed in the skin of patients with systemic sclerosis, pemphigus vulgaris, Behcet's disease, and psoriasis. These cells express Perforin and granzymes and demonstrate enhanced cytotoxicity in comparison to cells from healthy controls. They also exhibit increased IFN-g expression. (C) Cutaneous GD T cells also express the newly discovered innate immune protein Perforin-2. Unlike other MACPF pore formers, Perforin-2 localizes to endosomes that fuse with the phagosome upon intracellular bacterial infection, facilitating pore formation on the bacterial cell membrane. Perforin-2 is essential for the elimination of intracellular bacteria. Given the established role of GD T cells in the antimicrobial response, it is likely that damage to the skin barrier and bacterial entry into the skin contribute to Perforin-2 induction in these immune surveillance cells.

pro-tumor GD T cell phenotype. These results underscore the importance of Perforin as an effector molecule in GD T cell mediated cytotoxicity in the skin.
Despite the clear importance of Perforin expressing cytotoxic GD $\mathrm{T}$ cells in the cutaneous anti-tumor response, these cells have the potential to develop into aggressive $\mathrm{T}$ cell lymphomas 
$(56,57)$. Primary cutaneous GD T cell lymphomas constitute a subgroup of aggressive $\mathrm{T}$ cell lymphomas that express a mature cytotoxic phenotype. These tumors are characterized by their expression of T-cell-restricted intracellular antigen-1 (TIA-1), granzyme B, and Perforin (56-58) and there is also a strong correlation between CD30 expression and cytotoxic protein production (59). Cutaneous GD T cell lymphomas, while rare, have a poor prognosis; therefore, appropriate tumor phenotyping could be a useful tool for diagnosing this disease.

Perforin expressing GD $\mathrm{T}$ cells are also implicated in autoimmune and inflammatory skin diseases (Table 1). Patients with the autoimmune disease systemic sclerosis exhibit an increased percentage of Vdelta 1+ GD T cells that demonstrate cytotoxic activity in the skin $(69,70)$. Increased percentages of CD27+ GD T cells expressing Perforin and granzyme B are also present (71). Patients with Pemphigus vulgaris, an autoimmune disease that causes skin blistering, also have an increased percentage of circulating GD T cells. These cells demonstrate increased activation and cytotoxic activity in comparison to healthy controls (72). Behcet's disease, a disorder that causes blood vessel inflammation, is also associated with the expansion of GD $\mathrm{T}$ cells exhibiting increased Perforin and granzyme A expression $(73,74)$. Increased Perforin and granzyme B expression by $\mathrm{CD} 3+\mathrm{T}$ cells is also evident in the epidermis of psoriasis patients (75-77). Only the CD8+ and CD4+ T cell subsets were analyzed, so Perforin expression by GD T cells in psoriasis has not yet been confirmed. It has been confirmed, however, that dermal GD T cells are recruited to the epidermis in psoriasis by activated keratinocytes that produce the chemokines CCL2 and CCL20 (78). Recruited dermal GD $\mathrm{T}$ cells induce an innate-like immune response by producing IL-17 and IL-22 upon IL-1 and IL-23 stimulation. IL-1 is expressed by keratinocytes while IL-23 is expressed by dermal dendritic cells and macrophages. IL-17 and IL-22 production further drives keratinocyte hyperplasia, neutrophil recruitment and disease progression (5). Since pro-inflammatory GD T cells are recruited to psoriatic skin, they are likely to be among the Perforin expressing CD3 $+\mathrm{T}$ cells observed in psoriasis patients (Figure 1B). Overall, studies have shown that GD $\mathrm{T}$ cells in the skin express Perforin, and this is associated with an activated cytotoxic phenotype. This can contribute positively to skin immune function via induction of the anti-tumor immune response, or it may have deleterious effects in the case of autoimmune and inflammatory skin disorders or cutaneous GD T cell lymphomas.

\section{MECHANISMS REGULATING PERFORIN EXPRESSION IN SKIN GD T CELLS}

Although it is clear that cutaneous cytotoxic GD T cells express Perforin, the mechanisms that regulate its expression are still unclear. Perforin is copiously expressed once these cells become activated (18). In contrast to $\mathrm{CD} 8+\mathrm{AB} \mathrm{T}$ cells which require TCR binding to MHC for activation (79), cytotoxic GD T cells can become activated through a non-MHC-restricted mechanism (61). In fact, recognition and killing of target cells can proceed through ligation of several costimulatory surface molecules in the absence of TCR stimulation (53). One of these surface molecules is the activating $\mathrm{NK}$ receptor NKG2D. It recognizes the $\mathrm{MHC}$ class I polypeptide-related sequence A and B (MICA and MICB), which are induced on stressed cells (53). NKG2D is expressed by most NK and CD8+ AB T cells, but it was found that both mouse and human GD T cells constitutively express NKG2D as well (53, $80,81)$. Its expression is maintained during cell culture of freshly isolated GD T cells $(13,18,53)$. NKG2D ligation stimulates epidermal GD T cell degranulation using a phosphatidylinositol 3-kinase (PI3K)-dependent pathway, and killing of NKG2DL expressing target cells occurs in the absence of CD3 and TCR signaling (60). Treatment of skin GD T cells with anti-NKG2D antibodies impaired lysis of A20 B cell lymphoma cells, but treatment with anti-TCR antibodies had no effect, indicating that NKG2D signaling is sufficient to activate cytotoxicity in skin GD T cells (53). Skin GD T cells also express the surface glycoprotein 2B4. Removal of IL-2 from GD T cell culture media reduced surface expression of 2B4 and also reduced their capacity to lyse target cells (61). Their cytotoxicity was enhanced by treatment with a stimulatory anti-2B4 antibody, indicating the importance of this receptor in cutaneous GD $\mathrm{T}$ cell mediated cytotoxicity. B7-1 (CD80) also provides costimulatory signals to both $\mathrm{AB}$ and GD T cells by binding to CD28 on the T cell surface, increasing adhesion to the target cell. B7-1 surface expression on Pam212, murine squamous cell carcinoma cells, stimulated cutaneous GD $\mathrm{T}$ cell proliferation and increased carcinoma cell sensitivity to GD T cell mediated lysis (62). Cutaneous GD T cell cytotoxicity is regulated through expression of several inhibitory receptors that block cytotoxicity upon binding with their appropriate ligands. Murine skin GD T cells express the inhibitory receptors Ly49 and CD94/NKG2. Presentation with Qdm, the ligand for CD94/NKG2, prevented the epidermal GD T cells from killing target cells (67).

GD $\mathrm{T}$ cell cytotoxicity is also activated by their recognition of stress-induced molecules on target cell surfaces. Macrophages and neutrophils externalize the heat shock proteins Hsp60 and Hsp70 under inflammatory conditions to target them for destruction, thus resolving the inflammation and preventing excess tissue damage. Cytotoxic GD $\mathrm{T}$ cells recognize these molecules and kill the target cells via direct cell-cell interactions (64). Activation of Perforin expressing cytotoxic GD T cells is also mediated through cytokine expression. IL-2, IL-15, and IL-12 enhance cytolytic activity of cutaneous GD T cells, and the transcription factor IFN regulatory factor-1 (IRF1 ) is essential for induction of cytotoxicity $(61,63)$. The Perforin dependent anti-tumor properties of GD T cells can be enhanced pharmacologically. For example, rapamycin enhances the perforin-dependent cytotoxicity of human GD T cells against squamous cell carcinomas in vitro and in a mouse xenograft model of human squamous cell carcinoma (65). Additionally, Resveratrol enhances Perforin expression in NK cells through an NKG2D dependent pathway, implicating its potential to increase Perforin expression by NKG2D expressing GD T cells as well (82). Given the deleterious effects of Perforin expressing cells in the context of autoimmune and inflammatory disorders, blocking therapeutics targeting Perforin may benefit patients 
TABLE 1 | Perforins expressed by cutaneous GD T cells.

\begin{tabular}{|c|c|c|}
\hline & Perforin & Perforin-2 \\
\hline Location in the cell & $\begin{array}{l}\text { Intracellular cytolytic } \\
\text { granules (39) }\end{array}$ & $\begin{array}{l}\text { Membranes of intracellular } \\
\text { endosomes }(46,47)\end{array}$ \\
\hline $\begin{array}{l}\text { Function in GD T } \\
\text { cells }\end{array}$ & $\begin{array}{l}\text { Lysis of transformed or } \\
\text { infected cells (39-41) }\end{array}$ & $\begin{array}{l}\text { Destruction of intracellular } \\
\text { bacteria }(46,47)\end{array}$ \\
\hline Stimulatory factors & $\begin{array}{l}\text { Surface receptors: } \\
\text { - GD TCR (53) } \\
\text { - NKG2D (13, 18, 53, 60) } \\
\text { - 2B4 (61) } \\
\text { - B7-1 (62) } \\
\text { Cytokines: } \\
\text { - IL-2 (61) } \\
\text { - IL-12 (63) } \\
\text { - IL-15 (63) } \\
\text { Stress induced molecules: } \\
\text { - Hsp60 (64) } \\
\text { - Hsp70 (64) } \\
\text { Transcription Factors: } \\
\text { - IRF-1 (63) } \\
\text { Therapeutics: } \\
\text { - Rapamycin (65) }\end{array}$ & $\begin{array}{l}\text { Commensal bacteria: } \\
\text { - S. epidermidis (66) }\end{array}$ \\
\hline Inhibitory factors & $\begin{array}{l}\text { Surface receptors: } \\
\text { - Ly49 (67) } \\
\text { - CD94 (67) }\end{array}$ & $\begin{array}{l}\text { Pathogenic bacteria: } \\
\text { - S. aureus (68) }\end{array}$ \\
\hline Role in disease & $\begin{array}{l}\text { Expressed by cutaneous } \\
\text { GD T cell lymphomas } \\
\text { (56-59) } \\
\text { Upregulated in autoimmune } \\
\text { and inflammatory diseases: } \\
\text { - Systemic sclerosis } \\
\quad(69-71) \\
\text { - Pemphigus vulgaris }(72) \\
\text { - Behcet's disease }(73,74) \\
\text { - Psoriasis }(75-77)\end{array}$ & $\begin{array}{l}\text { Upregulated in response to } \\
\text { wounding (68) } \\
\text { Downregulation may } \\
\text { contribute to persistent } \\
\text { wound infection (68) }\end{array}$ \\
\hline
\end{tabular}

Summary of the information currently known about Perforin and Perforin-2 expression by cutaneous GD T cells. Listed are the location of the Perforins within the cell, functions of the Perforins in GD T cells, Perforin stimulatory and inhibitory factors, and the role of Perforins in cutaneous diseases.

suffering from these illnesses. Compounds identified as Perforin inhibitors in $\mathrm{NK}$ and $\mathrm{AB} \mathrm{T}$ cells include diarylthiophenes and benzenesulfonamide based therapeutics (83-85). In short, cutaneous GD T cells express Perforin upon activation and this activation can be achieved through a variety of mechanisms including stimulation of the TCR, ligation of costimulatory molecules, and cytokine stimulation (Table 1). The critical role of Perforin in executing GD T cell mediated cytotoxicity in the skin warrants further studies on the mechanisms that induce Perforin expression by these cells.

\section{PERFORIN-2 EXPRESSION BY GD T CELLS}

Perforin-2 is a recently identified member of the MACPF domain containing pore forming family of innate immune proteins that plays a critical role in clearance of intracellular bacterial infections. However, the mechanisms behind Perforin-2 activation and the extent of its contributions to host immunity have not been fully characterized. Our group was the first to report Perforin-2 expression in a variety of cell types in human skin including keratinocytes, fibroblasts and GD T cells (68). Although it is known that both murine and human GD T cells express Perforin-2, the role that it plays in GD $\mathrm{T}$ cell mediated cytotoxicity toward bacterial pathogens is still unknown. We demonstrated that Perforin-2 expression is upregulated in CD45+ cells upon wounding in an ex vivo human skin model. However, infection of the wounds with Staphylococcus aureus inhibited Perforin-2 expression in these cells (68). This indicates a potential role for Perforin-2 in promoting skin homeostasis and barrier integrity by aiding in the clearance of bacteria from the wound site (Figure 1C). This was confirmed by our finding that human keratinocyte cells constitutively expressing a Perforin-2-GFP fusion protein demonstrate improved clearance of intracellular $S$. aureus infection in comparison to control cells (68). Our group has also demonstrated that Perforin-2 deficient mice infected epicutaneously are unable to clear S. aureus and eventually succumb to the infection (48). Interestingly, in this issue we provide evidence that $S$. epidermidis, a skin commensal microorganism, induces Perforin-2 in GD $\mathrm{T}$ cells in human skin ex vivo (66). Given the established role of GD $\mathrm{T}$ cells in the antimicrobial response and in keratinocyte proliferation and migration upon wounding, it is likely that disruption of the epidermal barrier and signals from microorganisms can result in Perforin-2 induction. This warrants further studies on Perforin2 regulation and its function as an effector protein in GD $\mathrm{T}$ cell mediated skin immune responses.

\section{CONCLUSIONS}

Maintaining skin homeostasis and barrier function is essential for protection against physical and chemical stress, infections, and malignancies. Recent research has highlighted the significant contributions of GD T cells to skin health through their role in bacterial clearance, wound healing, and tumor killing. Expression of both Perforin and Perforin-2 by GD T cells has been implicated in the activation of these effector functions (Figure 1, Table 1). GD T cells lyse a variety of tumor cell lines and exhibit many characteristics of conventional cytotoxic T cells. Although GD T cells have been shown to produce Perforin, little is known about the signals that stimulate its expression. Additionally, Perforin2 was recently identified as another member of the MACPF domain containing pore forming protein family. It is critical for clearance of intracellular bacterial infections, and it is expressed constitutively by GD T cells. Given the established role of GD $\mathrm{T}$ cells as first responders to bacterial infections in the skin, it is important to further investigate the regulation of Perforin2 in this GD $\mathrm{T}$ cell function. Understanding the signals that activate Perforin expression by GD T cells can help to elucidate the mechanisms governing their diverse roles in skin immunity.

\section{AUTHOR CONTRIBUTIONS}

KO'N wrote the manuscript and prepared the figures. IP, MT-C, and NS revised the manuscript and provided critical comments. All authors contributed to the article and approved the submitted version. 


\section{FUNDING}

This work was supported by NIH NR015649 (MT-C and NS), DK119085 (MT-C), Dwoskin family gift to the Dr. Phillip Frost Department of Dermatology and Cutaneous Surgery (MT-C) and by Department of Microbiology and Immunology P2 funds (NS).

\section{REFERENCES}

1. Chien Y, Meyer C, Bonneville M. $\gamma \delta$ T cells: first line of defense and beyond. Annu Rev Immunol. (2014) 32:12155. doi: 10.1146/annurev-immunol-032713-120216

2. Havran WL, Jameson JM, Witherden DA. Epithelial cells and their neighbors. III. Interactions between intraepithelial lymphocytes and neighboring epithelial cells. Am J Physiol Liver Physiol. (2005) 289:G627-30. doi: 10.1152/ajpgi.00224.2005

3. Groh V, Porcelli S, Fabbi M, Lanier LL, Picker LJ, Anderson T, et al. Human lymphocytes bearing $\mathrm{T}$ cell receptor gamma/delta are phenotypically diverse and evenly distributed throughout the lymphoid system. J Exp Med. (1989) 169:1277-94. doi: 10.1084/jem.169.4.1277

4. Parker CM, Groh V, Band H, Porcelli SA, Morita C, Fabbi M, et al. Evidence for extrathymic changes in the T cell receptor gamma/delta repertoire. J Exp Med. (1990) 171:1597-612. doi: 10.1084/jem.171.5.1597

5. Cai Y, Shen X, Ding C, Qi C, Li K, Li X, et al. Pivotal role of dermal IL17-producing $\gamma \delta \mathrm{T}$ cells in skin inflammation. Immunity. (2011) 35:596610. doi: 10.1016/j.immuni.2011.08.001

6. Gray EE, Suzuki K, Cyster JG. Cutting edge: identification of a motile IL-17producing gammadelta $\mathrm{T}$ cell population in the dermis. J Immunol. (2011) 186:6091-5. doi: 10.4049/jimmunol.1100427

7. Itohara S, Farr AG, Lafaille JJ, Bonneville M, Takagaki Y, Haas W, et al. Homing of a $\gamma \delta$ thymocyte subset with homogeneous T-cell receptors to mucosal epithelia. Nature. (1990) 343:754-7. doi: 10.1038/343754a0

8. Goodman T, Lefrancois L. Intraepithelial lymphocytes. Anatomical site, not $\mathrm{T}$ cell receptor form, dictates phenotype and function. J Exp Med. (1989) 170:1569-81. doi: 10.1084/jem.170.5.1569

9. Laggner U, Di Meglio P, Perera GK, Hundhausen C, Lacy KE, Ali N, et al. Identification of a novel proinflammatory human skin-homing $\mathrm{V} \gamma 9 \mathrm{~V} \delta 2 \mathrm{~T}$ cell subset with a potential role in psoriasis. J Immunol. (2011) 187:278393. doi: 10.4049/jimmunol.1100804

10. Witherden DA, Havran WL. Cross-talk between intraepithelial $\gamma \delta \mathrm{T}$ cells and epithelial cells. J Leukoc Biol. (2013) 94:69-76. doi: 10.1189/jlb.0213101

11. Whang MI, Guerra N, Raulet DH. Costimulation of dendritic epidermal $\gamma \delta$ $\mathrm{T}$ cells by a new NKG2D ligand expressed specifically in the skin. J Immunol. (2009) 182:4557-64. doi: 10.4049/jimmunol.0802439

12. Bonneville M, O’Brien RL, Born WK. $\gamma \delta \mathrm{T}$ cell effector functions: a blend of innate programming and acquired plasticity. Nat Rev Immunol. (2010) 10:467-78. doi: $10.1038 /$ nri2781

13. Strid J, Sobolev O, Zafirova B, Polic B, Hayday A. The intraepithelial T cell response to NKG2D-ligands links lymphoid stress surveillance to atopy. Science. (2011) 334:1293-7. doi: 10.1126/science.1211250

14. Havran WL, Allison JP. Origin of Thy-1+ dendritic epidermal cells of adult mice from fetal thymic precursors. Nature. (1990) 344:6870. doi: $10.1038 / 344068 \mathrm{a} 0$

15. Bos JD, Teunissen MBM, Cairo I, Krieg SR, Kapsenberg ML, Das PK, et al. TCell receptor $\gamma \delta$ bearing cells in normal human skin. J Invest Dermatol. (1990) 94:37-42. doi: 10.1111/1523-1747.ep12873333

16. Clark RA, Chong B, Mirchandani N, Brinster NK, Yamanaka K-I, Dowgiert $\mathrm{RK}$, et al. The vast majority of CLA $+\mathrm{T}$ cells are resident in normal skin. $J$ Immunol. (2006) 176:4431-9. doi: 10.4049/jimmunol.176.7.4431

17. Alaibac M, Morris J, Yu R, Chu AC. T lymphocytes bearing the $\gamma \delta$ T-cell receptor: a study in normal human skin and pathological skin conditions. $\mathrm{Br}$ J Dermatol. (1992) 127:458-62. doi: 10.1111/j.1365-2133.1992.tb14840.x

18. Ebert LM, Meuter S, Moser B. Homing and function of human skin gammadelta T cells and NK cells: relevance for tumor surveillance. J Immunol. (2006) 176:4331-6. doi: 10.4049/jimmunol.176.7.4331

\section{ACKNOWLEDGMENTS}

We dedicate this work to the late Dr. Eckhard Podack without whom studies of Perforin-2 would not be possible. We are grateful to all members of Tomic-Canic and Strbo laboratories for their overall support.

19. Cruz MS, Diamond A, Russell A, Jameson JM. Human $\alpha \beta$ and $\gamma \delta \mathrm{T}$ cells in skin immunity and disease. Front Immunol. (2018) 9:1304. doi: 10.3389/fimmu.2018.01304

20. Vantourout P, Hayday A. Six-of-the-best: unique contributions of $\gamma \delta \mathrm{T}$ cells to immunology. Nat Rev Immunol. (2013) 13:88-100. doi: 10.1038/nri3384

21. Morita CT, Lee HK, Leslie DS, Tanaka Y, Bukowski JF, Märker-Hermann E. Recognition of nonpeptide prenyl pyrophosphate antigens by human $\gamma \delta \mathrm{T}$ cells. Microbes Infect. (1999) 1:175-86. doi: 10.1016/S1286-4579(99) 80032-X

22. Sumaria N, Roediger B, Ng LG, Qin J, Pinto R, Cavanagh LL, et al. Groth B, Triccas JA, Weninger W. Cutaneous immunosurveillance by selfrenewing dermal $\gamma \delta$ T cells. J Exp Med. (2011) 208:505-18. doi: 10.1084/jem. 20101824

23. Pantelyushin S, Haak S, Ingold B, Kulig P, Heppner FL, Navarini AA, et al. Ror $\gamma \mathrm{t}+$ innate lymphocytes and $\gamma \delta \mathrm{T}$ cells initiate psoriasiform plaque formation in mice. J Clin Invest. (2012) 122:2252-6. doi: 10.1172/JCI61862

24. Toulon A, Breton L, Taylor KR, Tenenhaus M, Bhavsar D, Lanigan C, et al. A role for human skin-resident T cells in wound healing. J Exp Med. (2009) 206:743-50. doi: 10.1084/jem.20081787

25. Jameson J, Ugarte K, Chen N, Yachi P, Fuchs E, Boismenu R, et al. A role for skin gamma delta T cells in wound repair. Science. (2002) 296:7479. doi: 10.1126/science.1069639

26. MacLeod AS, Hemmers S, Garijo O, Chabod M, Mowen K, Witherden DA, et al. Dendritic epidermal T cells regulate skin antimicrobial barrier function. J Clin Invest. (2013) 123:4364-74. doi: 10.1172/JCI70064

27. Gay D, Kwon O, Zhang Z, Spata M, Plikus M V, Holler PD, et al. Fgf9 from dermal $\gamma \delta \mathrm{T}$ cells induces hair follicle neogenesis after wounding. Nat Med. (2013) 19:916-23. doi: 10.1038/nm.3181

28. Kaminski MJ, Cruz PD, Bergstresser PR, Takashima A. Killing of skin-derived tumor cells by mouse dendritic epidermal T-cells. Cancer Res. (1993) 53:40149

29. Girardi M, Oppenheim DE, Steele CR, Lewis JM, Glusac E, Filler R, et al. Regulation of cutaneous malignancy by gamma delta T Cells. Science. (2001) 294:605-9. doi: 10.1126/science.1063916

30. Rosado CJ, Kondos S, Bull TE, Kuiper MJ, Law RHP, Buckle AM, et al. The MACPF/CDC family of pore-forming toxins. Cell Microbiol. (2008) 10:1765-74. doi: 10.1111/j.1462-5822.2008.01191.x

31. Gilbert RJC. Cholesterol-dependent cytolysins. Adv Exp Med Biol. (2010) 677:56-66. doi: 10.1007/978-1-4419-6327-7_5

32. Tweten RK. Cholesterol-dependent cytolysins, a family of versatile pore-forming toxins. Infect Immun. (2005) 73:6199209. doi: 10.1128/IAI.73.10.6199-6209.2005

33. Hadders MA, Beringer DX, Gros P. Structure of C $8 \alpha$-MACPF reveals mechanism of membrane attack in complement immune defense. Science. (2007) 317:1552-4. doi: 10.2210/pdb2qqh/pdb

34. Rosado CJ, Buckle AM, Law RHP, Butcher RE, Kan WT, Bird CH, et al. A common fold mediates vertebrate defense and bacterial attack. Science. (2007) 317:1548-51. doi: 10.1126/science. 1144706

35. Slade DJ, Lovelace LL, Chruszcz M, Minor W, Lebioda L, Sodetz JM. Crystal structure of the MACPF domain of human complement protein $\mathrm{C} 8 \alpha$ in complex with the C8 $\gamma$ subunit. J Mol Biol. (2008) 379:33142. doi: 10.1016/j.jmb.2008.03.061

36. Tschopp J, Masson D, Stanley KK. Structural/functional similarity between proteins involved in complement- and cytotoxic T-lymphocyte-mediated cytolysis. Nature. (1986) 322:831-4. doi: 10.1038/322831a0

37. Lovelace LL, Cooper CL, Sodetz JM, Lebioda L. Structure of human C8 protein provides mechanistic insight into membrane pore formation by complement. J Biol Chem. (2011) 286:17585-92. doi: 10.1074/jbc.M111.219766 
38. Kondos SC, Hatfaludi T, Voskoboinik I, Trapani JA, Law RHP, Whisstock JC, et al. The structure and function of mammalian membrane-attack complex/perforin-like proteins. Tissue Antigens. (2010) 76:341-51. doi: 10.1111/j.1399-0039.2010.01566.x

39. Podack ER, Young JDE, Cohn ZA. Isolation and biochemical and functional characterization of perforin 1 from cytolytic T-cell granules. Proc Natl Acad Sci USA. (1985) 82:8629-33. doi: 10.1073/pnas.82.24.8629

40. Lopez JA, Susanto O, Jenkins MR, Lukoyanova N, Sutton VR, Law RHP, et al. Perforin forms transient pores on the target cell plasma membrane to facilitate rapid access of granzymes during killer cell attack. Blood. (2013) 121:2659-68. doi: 10.1182/blood-2012-07-446146

41. Leung C, Hodel AW, Brennan AJ, Lukoyanova N, Tran S, House CM, et al. Real-time visualization of perforin nanopore assembly. Nat Nanotechnol. (2017) 12:467-73. doi: 10.1038/nnano.2016.303

42. Benard EL, Racz PI, Rougeot J, Nezhinsky AE, Verbeek FJ, Spaink HP, et al. Macrophage-expressed perforins mpeg1 and mpeg1.2 have an anti-bacterial function in zebrafish. J Innate Immun. (2015) 7:13652. doi: 10.1159/000366103

43. Wiens M, Korzhev M, Krasko A, Thakur NL, Perović-Ottstadt S, Breter HJ, et al. Innate immune defense of the sponge suberites domuncula against bacteria involves a myD88-dependent signaling pathway. J Biol Chem. (2005) 280:27949-59. doi: 10.1074/jbc.M504049200

44. McCormack R, Podack ER. Perforin-2/Mpeg1 and other poreforming proteins throughout evolution. J Leukoc Biol. (2015) 98:761-8. doi: 10.1189/jlb.4MR1114-523RR

45. D'Angelo ME, Dunstone MA, Whisstock JC, Trapani JA, Bird PI. Perforin evolved from a gene duplication of MPEG1, followed by a complex pattern of gene gain and loss within luteleostomi. BMC Evol Biol. (2012) 12:59. doi: 10.1186/1471-2148-12-59

46. Ni T, Jiao F, Yu X, Aden S, Ginger L, Williams SI, et al. Structure and mechanism of bactericidal mammalian perforin-2, an ancient agent of innate immunity. Sci Adv. (2020) 6:eaax8286. doi: 10.1126/sciadv.aax8286

47. Pang SS, Bayly-Jones C, Radjainia M, Spicer BA, Law RHP, Hodel AW, et al. The cryo-EM structure of the acid activatable pore-forming immune effector macrophage-expressed gene 1. Nat Commun. (2019) 10:4288. doi: 10.1038/s41467-019-12279-2

48. McCormack RM, de Armas LR, Shiratsuchi M, Fiorentino DG, Olsson ML, Lichtenheld MG, et al. Perforin-2 is essential for intracellular defense of parenchymal cells and phagocytes against pathogenic bacteria. Elife. (2015) 4:e508. doi: 10.7554/eLife.06508

49. McCormack R, de Armas LR, Shiratsuchi M, Ramos JE, Podack ER. Inhibition of intracellular bacterial replication in fibroblasts is dependent on the perforin-like protein (perforin-2) encoded by macrophage-expressed gene 1 . J Innate Immun. (2013) 5:185-94. doi: 10.1159/000345249

50. Smyth MJ, Ortaldo JR, Shinkaij YI, Yagita H, Nakata M, Okumura K, et al. Interleukin 2 induction of pore-forming protein gene expression in human peripheral blood CD8+ T cells. J Exp Med. (1990) 171:126981. doi: 10.1084/jem.171.4.1269

51. Krähenbühl O, Gattesco S, Tschopp J. Murine Thy-1+ dendritic epidermal $t$ cell lines express granule-associated perforin and a family of granzyme molecules. Immunobiology. (1992) 184:392401. doi: 10.1016/S0171-2985(11)80596-6

52. Kägi D, Ledermann B, Bürki K, Zinkernagel RM, Hengartner H. Molecular mechanisms of lymphocyte-mediated cytotoxicity and their role in immunological protection and pathogenesis in vivo. Annu Rev Immunol. (1996) 14:207-32. doi: 10.1146/annurev.immunol.14.1.207

53. Nitahara A, Shimura H, Ito A, Tomiyama K, Ito $M$, Kawai K. NKG2D ligation without $\mathrm{T}$ cell receptor engagement triggers both cytotoxicity and cytokine production in dendritic epidermal T Cells. J Invest Dermatol. (2006) 126:1052-8. doi: 10.1038/sj.jid.5700112

54. Campillo JA, Martínez-Escribano JA, Minguela A, López-Álvarez R, Marín LA, García-Alonso AM, et al. Increased number of cytotoxic CD3+CD28- $\gamma \delta$ $\mathrm{T}$ cells in peripheral blood of patients with cutaneous malignant melanoma. Dermatology. (2007) 214:283-8. doi: 10.1159/000100878

55. Wakita D, Sumida K, Iwakura Y, Nishikawa H, Ohkuri T, Chamoto K, et al. Tumor-infiltrating IL-17-producing $\gamma \delta \mathrm{T}$ cells support the progression of tumor by promoting angiogenesis. Eur J Immunol. (2010) 40:192737. doi: 10.1002/eji.200940157
56. Toro JR, Beaty M, Sorbara L, Turner ML, White J, Kingma DW, et al. $\gamma \delta$ T-cell lymphoma of the skin. Arch Dermatol. (2000) 136:102432. doi: 10.1001/archderm.136.8.1024

57. Rodríguez-Pinilla SM, Ortiz-Romero PL, Monsalvez V, Tomás IE, Almagro $\mathrm{M}$, Sevilla A, et al. TCR- $\gamma$ expression in primary cutaneous T-cell lymphomas. Am J Surg Pathol. (2013) 37:375-84. doi: 10.1097/PAS.0b013e318275d1a2

58. Salhany KE, Macon WR, Choi JK, Elenitsas R, Lessin SR, Felgar RE, et al. Subcutaneous panniculitis-like T-cell lymphoma. Am J Surg Pathol. (1998) 22:881-93. doi: 10.1097/00000478-199807000-00010

59. Boulland ML, Wechsler J, Bagot M, Pulford K, Kanavaros P, Gaulard P. Primary CD30-positive cutaneous T-cell lymphomas and lymphomatoid papulosis frequently express cytotoxic proteins. Histopathology. (2000) 36:136-44. doi: 10.1046/j.1365-2559.2000.00799.x

60. Ibusuki A, Kawai K, Yoshida S, Uchida Y, Nitahara-Takeuchi A, Kuroki K, et al. NKG2D triggers cytotoxicity in murine epidermal $\gamma \delta \mathrm{T}$ cells via PI3Kdependent, Syk/ZAP70-independent signaling pathway. J Invest Dermatol. (2014) 134:396-404. doi: 10.1038/jid.2013.353

61. Schuhmachers G, Ariizumi K, Mathew PA, Bennett M, Kumar V, Takashima A. 2B4, a new member of the immunoglobulin gene superfamily, is expressed on murine dendritic epidermal $\mathrm{T}$ cells and plays a functional role in their killing of skin tumors. J Invest Dermetol. (1995). 105:5926. doi: 10.1111/1523-1747.ep12323533

62. Yeh K-Y, Zhong C, Nasir A, Ohsuga Y, Takashima A, Lord EM, et al. Expression of B7-1 by pam 212 squamous cell carcinoma enhances tumor cell interactions with dendritic epidermal $t$ cells but does not affect in vivo tumor growth. J Invest Dermatol. (1997). 109:728-33. doi: 10.1111/1523-1747.ep12340723

63. De Creus A, Van Beneden K, Stevenaert F, Debacker V, Plum J, Leclercq G. Developmental and functional defects of thymic and epidermal $\mathrm{V}$ gamma 3 cells in IL-15-deficient and IFN regulatory factor-1-deficient mice. J Immunol. (2002) 168:6486-93. doi: 10.4049/jimmunol.168.12.6486

64. Hirsh MI, Junger WG. Roles of heat shock proteins and gamma delta T cells in inflammation. Am J Respir Cell Mol Biol. (2008) 39:50913. doi: $10.1165 / \mathrm{rcmb} .2008-0090 \mathrm{TR}$

65. Dao V, Liu Y, Pandeswara S, Svatek RS, Gelfond JA, Liu A, et al. Immunestimulatory effects of rapamycin are mediated by stimulation of antitumor $\gamma \delta$ T cells. Cancer Res. (2016) 76:5970-82. doi: 10.1158/0008-5472.CAN-16-0091

66. Strbo N, O’Neill KE, Head CR, Padula L, Stojadinovic O, Pastar I, et al. Staphylococcus epidermidis facilitates intracellular pathogen clearance through upregulation of antimicrobial protein perforin-2 (P-2) in the human skin gamma delta T cells. J Immunol. (2020) 204(1 Supplement):157.10.

67. Van Beneden K, De Creus A, Stevenaert F, Debacker V, Plum J, Leclercq G. Expression of inhibitory receptors ly49e and cd94/nkg2 on fetal thymic and adult epidermal tcr v $\gamma 3$ lymphocytes. J Immunol. (2002) 168:3295302. doi: 10.4049/jimmunol.168.7.3295

68. Strbo N, Pastar I, Romero L, Chen V, Vujanac M, Sawaya AP, et al. Single cell analyses reveal specific distribution of anti-bacterial molecule perforin-2 in human skin and its modulation by wounding and Staphylococcus aureus infection. Exp Dermatol. (2019) 28:225-32. doi: 10.1111/exd.13870

69. Giacomelli R, Cipriani P, Fulminis A, Barattelli G, Matucci-Cerinic M, D’Alo $\mathrm{S}$, et al. Circulating gamma/delta T lymphocytes from systemic sclerosis (SSc) patients display a T helper (Th) 1 polarization. Clin Exp Immunol. (2001) 125:310-5. doi: 10.1046/j.1365-2249.2001.01603.x

70. Giacomelli R, Matucci-Cerinic M, Cipriani P, Ghersetich I, Lattanzio R, Pavan A, et al. Circulating V $\delta 1+\mathrm{T}$ cells are activated and accumulate in the skin of systemic sclerosis patients. Arthritis Rheum. (1998) 41:32734. doi: 10.1002/1529-013141:2<327::AID-ART17>3.0.CO;2-S

71. Henriques A, Silva C, Santiago M, Henriques MJ, Martinho A, Trindade $\mathrm{H}$, et al. Subset-specific alterations in frequencies and functional signatures of $\gamma \delta \mathrm{T}$ cells in systemic sclerosis patients. Inflamm Res. (2016) 65:98594. doi: 10.1007/s00011-016-0982-6

72. Das D, Anand V, Khandpur S, Sharma VK, Sharma A. T helper type 1 polarizing $\gamma \delta \mathrm{T}$ cells and scavenger receptors contribute to the pathogenesis of pemphigus vulgaris. Immunology. (2018) 153:97104. doi: 10.1111/imm. 12814

73. Accardo-Palumbo A, Giardina AR, Ciccia F, Ferrante A, Principato A, Impastato $\mathrm{R}$, et al. Phenotype and functional changes of $\mathrm{V} \gamma 9 / \mathrm{V} \delta 2 \mathrm{~T}$ lymphocytes in behçet's disease and the effect of infliximab on $\mathrm{V} \gamma 9 / \mathrm{V} \delta 2 \mathrm{~T}$ 
cell expansion, activation and cytotoxicity. Arthritis Res Ther. (2010) 12:R109. doi: 10.1186/ar3043

74. Cañete JD, Celis R, Noordenbos T, Moll C, Gómez-Puerta JA, Pizcueta P, et al. Distinct synovial immunopathology in Behçet disease and psoriatic arthritis. Arthritis Res Ther. (2009) 11:R17. doi: 10.1186/ar2608

75. Kastelan M, Prpic Massari L, Gruber F, Zamolo G, Zauhar G, Coklo M, et al. Perforin expression is upregulated in the epidermis of psoriatic lesions. $\mathrm{Br} \mathrm{J}$ Dermatol. (2004) 151:831-6. doi: 10.1111/j.1365-2133.2004.06168.x

76. Prpić Massari L, Kaštelan M, Laškarin G, Zamolo G, Massari D, Rukavina D. Analysis of perforin expression in peripheral blood and lesions in severe and mild psoriasis. J Dermatol Sci. (2007) 47:2936. doi: 10.1016/j.jdermsci.2007.02.007

77. Yawalkar N, Schmid S, Braathen LR, Pichler WJ. Perforin and granzyme B may contribute to skin inflammation in atopic dermatitis and psoriasis. $\mathrm{Br} J$ Dermatol. (2001) 144:1133-9. doi: 10.1046/j.1365-2133.2001.04222.x

78. Polese B, Zhang H, Thurairajah B, King IL. Innate lymphocytes in psoriasis. Front Immunol. (2020) 11:242. doi: 10.3389/fimmu.2020.00242

79. Bousso P, Robey E. Dynamics of CD8 $+\mathrm{T}$ cell priming by dendritic cells in intact lymph nodes. Nat Immunol. (2003) 4:579-85. doi: 10.1038/ni928

80. Maasho K, Opoku-Anane J, Marusina AI, Coligan JE, Borrego F. Cutting edge: NKG2D Is a costimulatory receptor for human naive CD8 + T Cells. J Immunol. (2005) 174:4480-4. doi: 10.4049/jimmunol.174.8.4480

81. Bauer S, Groh V, Wu J, Steinle A, Phillips JH, Lanier LL, et al. Activation of NK cells and T cells by NKG2D, a receptor for stress- inducible MICA. Science. (1999) 174:4480-4. doi: 10.1126/science.285.5428.727
82. Lu C-C, Chen J-K. Resveratrol enhances perforin expression and NK cell cytotoxicity through NKG2D-dependent pathways. J Cell Physiol. (2010) 223:343-51. doi: 10.1002/jcp.22043

83. Miller CK, Huttunen KM, Denny WA, Jaiswal JK, Ciccone A, Browne KA, et al. Diarylthiophenes as inhibitors of the pore-forming protein perforin. Bioorg Med Chem Lett. (2016) 26:355. doi: 10.1016/j.bmcl.2015.12.003

84. Spicer JA, Miller CK, O’Connor PD, Jose J, Huttunen KM, Jaiswal JK, et al. Benzenesulphonamide inhibitors of the cytolytic protein perforin. Bioorg Med Chem Lett. (2017) 27:1050-4. doi: 10.1016/j.bmcl.2016.12.057

85. Welz M, Eickhoff S, Abdullah Z, Trebicka J, Gartlan KH, Spicer JA, et al. Perforin inhibition protects from lethal endothelial damage during fulminant viral hepatitis. Nat Commun. (2018) 9:4805. doi: 10.1038/s41467-0 18-07213-x

Conflict of Interest: The authors declare that the research was conducted in the absence of any commercial or financial relationships that could be construed as a potential conflict of interest.

Copyright (C) 2020 O'Neill, Pastar, Tomic-Canic and Strbo. This is an open-access article distributed under the terms of the Creative Commons Attribution License (CC $B Y)$. The use, distribution or reproduction in other forums is permitted, provided the original author(s) and the copyright owner(s) are credited and that the original publication in this journal is cited, in accordance with accepted academic practice. No use, distribution or reproduction is permitted which does not comply with these terms. 